\title{
Automatic Control Systems for Fish Box Cooler
}

\author{
Gusrini Nelda Eviyanti* \\ Electrical Engineering Department \\ Universitas Maritim Raja Ali Haji \\ Indonesia
}

\author{
Eko Prayetno \\ Electrical Engineering Department \\ Universitas Maritim Raja Ali Haji \\ Indonesia
}

\author{
Sapta Nugraha \\ Electrical Engineering Department \\ Universitas Maritim Raja Ali Haji \\ Indonesia
}

*corresponding author: Gusrini Nelda Eviyanti,gusrininelda.eviyantikoto@gmail.com

\begin{abstract}
One factor is the low yields of fish fisheries production storage techniques are not maximal. In the system of fishing in Riau Islands, generally using small weights of motor boats, fishing gear and storage techniques are simple (conventional). Due to modern cooling system is quite expensive, fishermen only use containers containing ice cubes as a coolant to keep them fresh in a few hours. The objective of the study is, designing an automatic control system for fish box cooler with a constant temperature in the fish box. The device consists of the research is a heatsink, Peltier, temperature gauge, and pump. The device is a system in this study using a temperature sensor and Bluetooth. The results of sensor readings will be processed using the Arduino Uno is integrated with Bluetooth and then sent to the android application. The data are in the Android application will be monitored based on the desired temperature (setpoint).
\end{abstract}

Keywords - The cooling system, conventional techniques, Arduino Uno, android apps

\section{INTRODUCTION}

Riau Islands Province has more than $95 \%$ of marine waters, identifying the potential of fish resources contained in marine waters Kepri very much (BAPPEDA Kepri, 2016). Trend capture fisheries production in Riau Islands province over the last ten years (2005-2014) decreased by 23 percent, i.e. 181.118 tonnes in 2005 to 139.331 tonnes in 2014. High or low results fisheries production is influenced by many factors such as the efficiency of fishing gear, the term of arrest, as well as the quality of the arrest (BPS Kepri, 2015).

Most traditional fishermen Riau Islands still use conventional methods to store the catch of fish, mix ice cubes in a box. Its use is rated less than the maximum, due to the temperatures generated cannot survive long resulting in fish catches decompose faster. The cause of this is the absence of a cooling system of fish that last a long time according to the needs of traditional fishing in Riau Islands sailing within 1-2 days.

To maintain the freshness of the fish, requiring an automatic cooling system with a constant temperature inside the box of fish that can last a long time so that the freshness of the fish is maintained without the use of ice cubes. Based on these problems, was appointed to a study by implementing a design system that can control the temperature in the fish box automatically by adjusting the temperature in the cooler is maintained within 1-2 days sailing ship.

\section{LITERATURE REVIEW}

History of previous research studies became the foundation for the design of the control system of automatic cooling box fish by adjusting the temperature in the cooler is maintained.

The research "Construction of Storage Fish For Fisherman". This study designing fish storage for fishermen using traditional techniques refrigeration with a payload capacity of fish is limited and power capacity used is quite large. The process is done the same as the coolant in general, but the difference is the power system used. The advantages of this tool using a solar and kinetic force of the ship's engine as the power source itself. The results of this study are, a device designed capable of operating at temperatures of $-11^{\circ}$ $\mathrm{C}$ and long operating time 3 to 4 hours with a battery capacity of 120 Ah (Yadi and Pramana, 2017).

Next research "Cooling Device Designers Build on a squid". This study differs from previous research that uses refrigeration technique that can generate temperatures of up to minus (-) but uses a Peltier cooling system and heatsink. The results were Achieved when testing load the squid is getting the temperature at $14^{\circ} \mathrm{C}$ danger cooling time for 12 hours. The device uses less power, but the minimum temperature Obtained only reach $14^{\circ} \mathrm{C}$ (Anggara et al., 2018).

Based on the acquired theoretical basis, designed a control system cooling box automatic fish. Using the system as before, namely Peltier and heatsink. Advantages of the device compared to the previous study was obtained lower temperature is $2{ }^{\circ} \mathrm{C}$ and can control the cooling performance of the automatic and manual use android phone. 


\section{RESEARCH METHODOLOGY}

The system is controlled in these devices is the temperature used for freezing fish. In the working temperature automatically according to the given input so that the fish contained in the box to get a constant temperature.

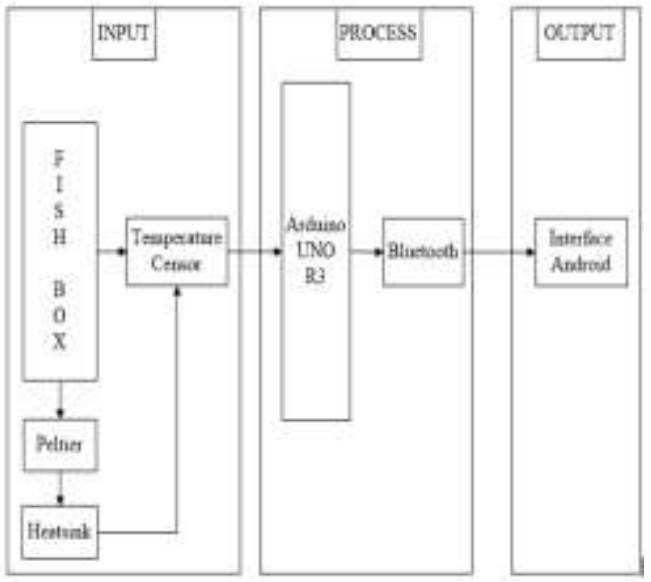

Figure 1. Diagram Design Tool

Figure 1 is a diagram of the design of the cooling device automatic fish box. Device working system is described in figure 2 .

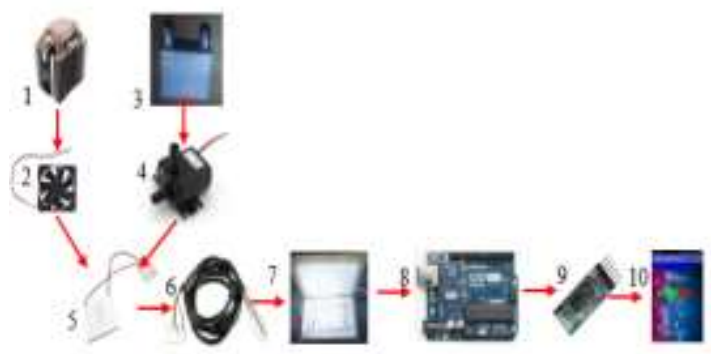

Figure 2. Device Design Research

Figure 2 is a hardware installation cooling section consisting of a heatsink (1), the fan (2), water block (3), and a water pump (4) connected to Peltier (5) as the cooling system. Part of the heat dissipation is a fan and Peltier blocks which circulate hot water through the wind and water that is the input device. The temperature sensor(6) as the temperature input delivery gained on fish box (7) which is arranged such that, subsequent temperature values obtained by the sensor in the process to Arduino UNO (8) as the microcontroller processing the input data from the temperature sensor to be delivered to Bluetooth (9) as the receiving input from the temperature sensor, will then be displayed the android system (10). The workings of the whole device will describe in Figure 3.

The workings of the cooling device are turned on study Began when the ship sailed. Then enter the fish into the cooler. After the Peltier and heatsink will work to cool the box until the desired temperature. In the second condition to be used if the temperature of the box $<2{ }^{\circ} \mathrm{C}$ then cooling will be automatically turned off, and the temperature is not $<2{ }^{\circ} \mathrm{C}$ then cooling to keep working until reaching a temperature adjusted. The next condition when the box temperature $>5^{\circ}$ $\mathrm{C}$ and $\geq 2{ }^{\circ} \mathrm{C}$ then cooling to keep working, but if the temperature is not $>5^{\circ} \mathrm{C}$ and $\geq 2{ }^{\circ} \mathrm{C}$, automatic cooling off.

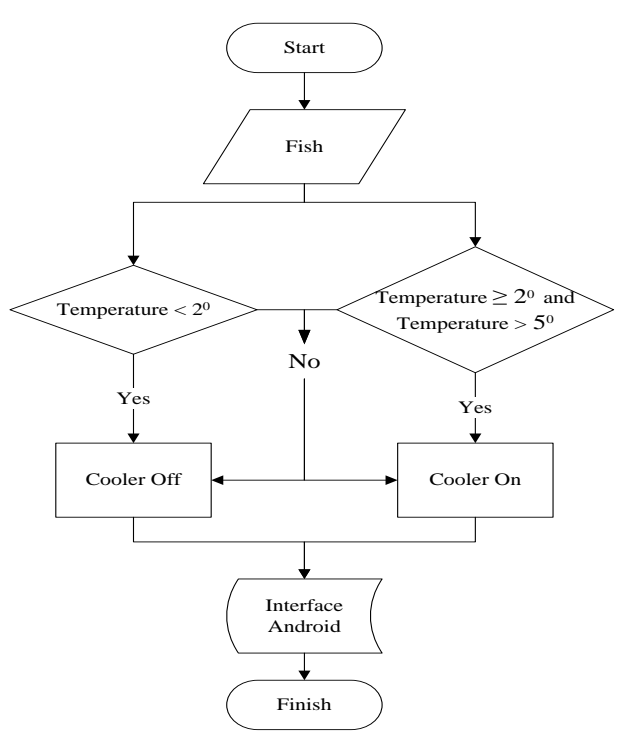

Figure 3. Flowchart System

The temperature used was $5^{\circ} \mathrm{C}-2^{\circ} \mathrm{C}$, according to a study Luckily Budiarto (2016) is suitable for sailing boat temperature $\geq 2$ days was $10-2{ }^{\circ} \mathrm{C}$. After that, the temperature sensor has been connected to the Arduino UNO R3 temperature read the data box, when the temperature according to the input, the process has been completed. If the temperature box did not correspond to the input temperature of the coolant to keep working until the desired temperature. Use of the Android interface serves as a temperature monitoring box and is used to control cooling.

\section{RESULTS AND DisCUSSION}

\section{A. Testing Power Supply}

Adapter used in this study is an adapter with a voltage of 12 VDC and a current of $30 \mathrm{~A}$. Observations was carried out by using a multimeter to measure the voltage adapter. In this section of the adapter output voltage observed.
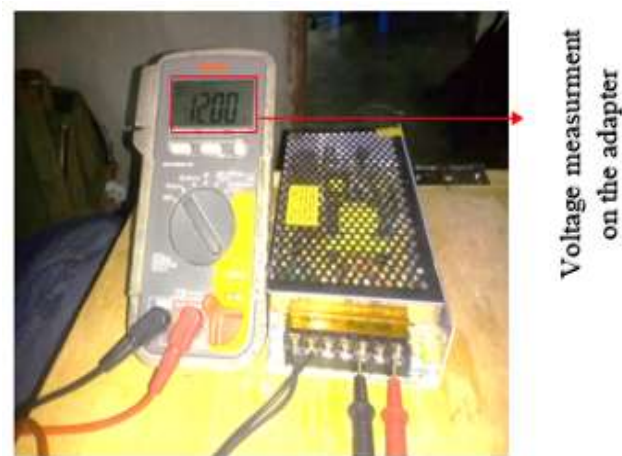

Figure 4. Voltage Measurement Testing

\section{B. Temperature Sensor Testing}

The temperature sensor used is a temperature sensor DS18B20 type that can survive in a moist state (Waterproof). 
Testing of temperature sensors in Figure 5 (a) and thermometer in Figure 5 (b).

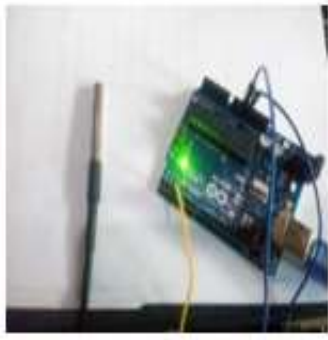

(a)

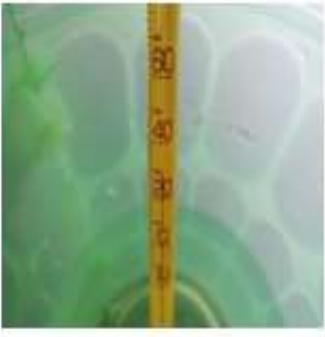

(b)
Figure 5. DS18B20 Temperature Sensor Testing (a) Testing Thermometer (b)

The measurement results using a comparison DS18B20 and thermometer.

Table 1. Comparison Test Temperature

\begin{tabular}{|l|c|c|c|}
\hline No & $\begin{array}{c}\text { Room } \\
\text { Condition }\end{array}$ & $\begin{array}{c}\text { Temperature } \\
\text { DS18B20 } \\
\left({ }^{0} \mathrm{C}\right)\end{array}$ & $\begin{array}{c}\text { Temperature } \\
\text { Thermometer } \\
\left({ }^{0} \mathrm{C}\right)\end{array}$ \\
\hline 1 & $\begin{array}{c}\text { Room } \\
\text { temperature }\end{array}$ & 28 & 29 \\
\hline 2 & $\begin{array}{c}\text { Outdoor } \\
\text { temperature }\end{array}$ & 30 & 32 \\
\hline
\end{tabular}

\section{Testing Android Applications and Bluetooth}

Android application testing is testing with reading a connected Bluetooth android application into the design. The following Figure 6 is an android application display screen connected by Bluetooth.

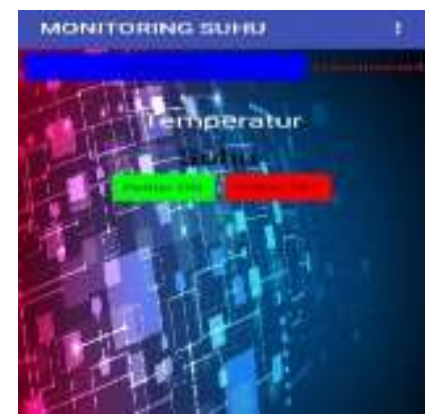

Figure 6. Screenshot Android App

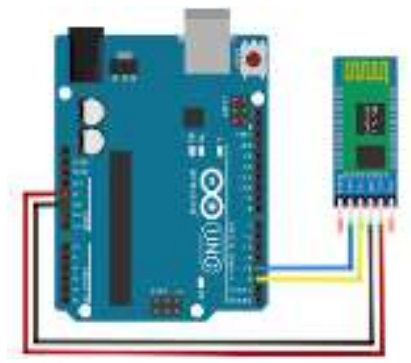

Figure 7. Testing Bluetooth

Testing is by connecting Bluetooth to Arduino UNO with testing distances read by android. From the Bluetooth test data unreadable within 8 meters, but within 7-8 meters obtained data connections are intermittent due to barriers such as boards, walls, and other obstacles, and at a distance of 9-10 meters Bluetooth sodium absorption ratio legible.

Table 2. Distance of Bluetooth

\begin{tabular}{|c|c|c|c|}
\hline \multirow{2}{*}{ No } & \multirow{2}{*}{$\begin{array}{l}\text { Distance } \\
\text { (Meter) }\end{array}$} & \multicolumn{2}{|c|}{ Condition } \\
\hline 1 & 1 & $\sqrt{ }$ & \\
\hline 2 & 2 & $\sqrt{ }$ & \\
\hline 3 & 3 & $\sqrt{ }$ & \\
\hline 4 & 4 & $\sqrt{ }$ & \\
\hline 5 & 5 & $\sqrt{ }$ & \\
\hline 6 & 6 & $\sqrt{ }$ & \\
\hline 7 & 7 & $\sqrt{ }$ & \\
\hline 8 & 8 & & $\sqrt{ }$ \\
\hline 9 & 9 & & $\sqrt{ }$ \\
\hline 10 & 10 & & \\
\hline
\end{tabular}

\section{Temperature Test Fish Box Without load}

From the test results the fish box without load, obtained a decrease in temperature from room temperature at $32^{\circ} \mathrm{C}$ takes \pm 5 hours to reach a temperature of $10^{\circ} \mathrm{C}$ in the time range between 13:00 to 14:00, and requires \pm 3 hours of temperature of $10^{\circ} \mathrm{C}$ to reach the lowest temperature ie $2^{0} \mathrm{C}$ in the time range between 15:00 to 16:00. After reaching the lowest temperature the fish box, the power supply is automatically switched off by the relay to the purpose of research, and if the temperature is rising to $>5^{\circ} \mathrm{C}$ then automatically turns the power supply to achieve the lowest temperature that the transition temperature of up to $10^{\circ} \mathrm{C}$.

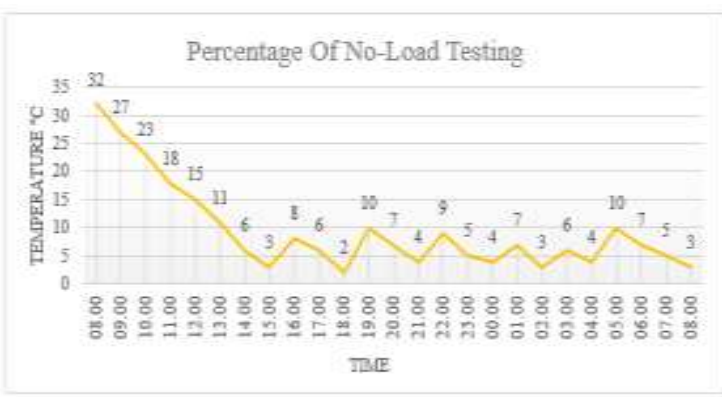

Figure 8. Temperature Test of Fish Box Without load (Fish)

Figure 8 shows a graph of temperature testing without a load; the temperature decreases gradually from its initial temperature of $32^{\circ} \mathrm{C}$ to $3^{\circ} \mathrm{C}$, the decline was the beginning of the current condition of the cooling work when the temperature reaches $<2^{\circ} \mathrm{C}$ automatic cooling die and the resulting temperature rise to $\geq 5^{\circ} \mathrm{C}$. Once the temperature reaches $\geq 5^{\circ} \mathrm{C}$ automatic cooling work. There $6-10^{\circ} \mathrm{C}$ transition temperature values for the cooling box.

Table 3. Temperature Test of Fish Box Without load (Fish) 


\begin{tabular}{|c|c|c|}
\hline No. & Time & Temperature $\left({ }^{0} \mathrm{C}\right)$ \\
\hline 1 & $08: 00$ & 32 \\
\hline 2 & $09: 00$ & 28 \\
\hline 3 & $10: 00$ & 25 \\
\hline 4 & $11: 00$ & 20 \\
\hline 5 & $12: 00$ & 17 \\
\hline 6 & $13: 00$ & 12 \\
\hline 7 & $14: 00$ & 10 \\
\hline 8 & $15: 00$ & 7 \\
\hline 9 & $16: 00$ & 6 \\
\hline 10 & $17: 00$ & 4 \\
\hline 11 & $18: 00$ & 2 \\
\hline 12 & $19: 00$ & 10 \\
\hline 13 & $20: 00$ & 8 \\
\hline 14 & $21: 00$ & 6 \\
\hline 15 & $22: 00$ & 5 \\
\hline 16 & $23: 00$ & 2 \\
\hline 17 & $24: 00$ & 8 \\
\hline 18 & $01: 00$ & 7 \\
\hline 19 & $02: 00$ & 4 \\
\hline 20 & $03: 00$ & 3 \\
\hline 21 & $04: 00$ & 6 \\
\hline 22 & $05: 00$ & 4 \\
\hline 23 & $06: 00$ & 10 \\
\hline 24 & $07: 00$ & 3 \\
\hline 25 & $08: 00$ & \\
\hline & & 3 \\
\hline
\end{tabular}

The minimum temperature decrease occurs up to temperatures of $2^{0} \mathrm{C}$ and a maximum temperature rise occurred to a temperatur $10^{\circ} \mathrm{C}$.

\section{E. Temperature Test Fish Box with Half Full Load}

Results of testing the load fish box half full (half load box volume capacity of $5 \mathrm{~kg}$ fish, showed a decrease in temperature from room temperature at $32^{\circ} \mathrm{C}$ takes \pm 6 hours to reach a temperature of $100 \mathrm{C}$ at the time of $14: 00$, and requires \pm 4 hours to reach the lowest temperature of $10^{\circ} \mathrm{C}$ becomes $2^{0} \mathrm{C}$ at the time of 18:00. After reaching the lowest temperature is the $2^{0} \mathrm{C}$ fish box at 18:00, power supply is automatically switched off by the relay.

Figure 9 shows a graph of temperature testing is half full load; the temperature decreases gradually from its initial temperature of $32^{\circ} \mathrm{C}$ to $-2^{0} \mathrm{C}$ longer than the no-load temperature test chart. The decline was the initial condition when the air-conditioner worked, when the temperature reaches $<2{ }^{0} \mathrm{C}$ automatic cooling die and the resulting.

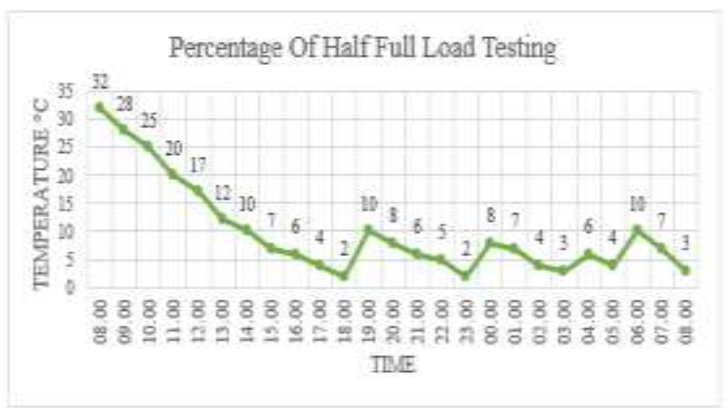

Figure 9. The temperature of Fish Box with Half Full Load
Temperature rise to $\geq 5^{0} \mathrm{C}$. Once the temperature reaches $5^{\circ} \mathrm{C} \geq$ automatic cooling work. There $6-10^{\circ} \mathrm{C}$ transition temperature values for the cooling box. Then $2^{\circ} \mathrm{C}$ temperature rise to a temperature of $10^{\circ} \mathrm{C}$, the temperature rises significantly is because the box contains a load resulting drop in temperature longer than without the load chart. The minimum temperature decrease occurs up to temperatures of $2^{\circ} \mathrm{C}$ and a maximum temperature rise occurred to a temperature of $10^{\circ} \mathrm{C}$.

Table 4.Temperature of Fish Box with Half Full Load

\begin{tabular}{|c|c|c|}
\hline No. & Time & Temperature $\left({ }^{0} \mathrm{C}\right)$ \\
\hline 1 & $08: 00$ & 32 \\
\hline 2 & $09: 00$ & 27 \\
\hline 3 & $10: 00$ & 23 \\
\hline 4 & $11: 00$ & 18 \\
\hline 5 & $12: 00$ & 15 \\
\hline 6 & $13: 00$ & 11 \\
\hline 7 & $14: 00$ & 6 \\
\hline 8 & $15: 00$ & 3 \\
\hline 9 & $16: 00$ & 8 \\
\hline 10 & $17: 00$ & 6 \\
\hline 11 & $18: 00$ & 2 \\
\hline 12 & $19: 00$ & 10 \\
\hline 13 & $20: 00$ & 7 \\
\hline 14 & $21: 00$ & 4 \\
\hline 15 & $22: 00$ & 9 \\
\hline 16 & $23: 00$ & 5 \\
\hline 17 & $00: 00$ & 2 \\
\hline 18 & $01: 00$ & 7 \\
\hline 19 & $02: 00$ & 3 \\
\hline 20 & $03: 00$ & 6 \\
\hline 21 & $04: 00$ & 4 \\
\hline 22 & $05: 00$ & 10 \\
\hline 23 & $06: 00$ & 7 \\
\hline 24 & $07: 00$ & 3 \\
\hline 25 & $08: 00$ & \\
\hline & & 2 \\
\hline
\end{tabular}

\section{F. Temperature Test Fish Box Full Load Testing}

Results of testing the fish box full load (full load capacity of $10 \mathrm{~kg}$ fish box), showed a decrease in temperature from room temperature at $32^{\circ} \mathrm{C}$ takes \pm 10 hours to reach a temperature of 100C between 18:00 to 19:00, and requires \pm 6 hours of temperature $10^{\circ} \mathrm{C}$ to reach the lowest temperature is $2^{\circ} \mathrm{C}$ at the time of $24: 00$.

Figure 10 shows a graph of full load temperature test, with a temperature decrease gradually from its initial temperature of $32^{\circ} \mathrm{C}$ to $-2^{0} \mathrm{C}$ longer than temperature test chart without the burden and expense half full. The decline was the initial condition when the air-conditioner worked, when the temperature reaches $<2^{0} \mathrm{C}$ automatic cooling die and the resulting temperature rise to $\geq 5^{0} \mathrm{C}$. Once the temperature reaches $\geq 5^{\circ} \mathrm{C}$ automatic cooling work. There 6$10^{\circ} \mathrm{C}$ transition temperature values for the cooling box. Then the temperature of $2^{\circ} \mathrm{C}$ to $8^{0} \mathrm{C}$ temperature. The rapid temperature increase due to the box contains a full load, then the drop in temperature longer than the no-load and load chart is half full. The minimum temperature decrease occurs up to temperatures of $2^{0} \mathrm{C}$ and a maximum temperature rise occurred to a temperature of $10^{\circ} \mathrm{C}$. 
Table 5. The temperature of Fish Box with Full Load

\begin{tabular}{|c|c|c|}
\hline No. & Time & Temperature $\left({ }^{0} \mathrm{C}\right)$ \\
\hline 1 & 08:00 & 32 \\
\hline 2 & 09:00 & 30 \\
\hline 3 & $10: 00$ & 28 \\
\hline 4 & 11:00 & 26 \\
\hline 5 & $12: 00$ & 25 \\
\hline 6 & 13:00 & 22 \\
\hline 7 & 14:00 & 19 \\
\hline 8 & 15:00 & 18 \\
\hline 9 & $16: 00$ & 16 \\
\hline 10 & $17: 00$ & 14 \\
\hline 11 & $18: 00$ & 11 \\
\hline 12 & 19:00 & 9 \\
\hline 13 & 20:00 & 7 \\
\hline 14 & 21:00 & 6 \\
\hline 15 & $22: 00$ & 4 \\
\hline 16 & 23:00 & 3 \\
\hline 17 & 24:00 & 2 \\
\hline 18 & 01:00 & 8 \\
\hline 19 & 02:00 & 6 \\
\hline 20 & 03:00 & 5 \\
\hline 21 & 04:00 & 3 \\
\hline 22 & 05:00 & 6 \\
\hline 23 & 06:00 & 4 \\
\hline 24 & 07:00 & 2 \\
\hline 25 & 08:00 & 10 \\
\hline
\end{tabular}

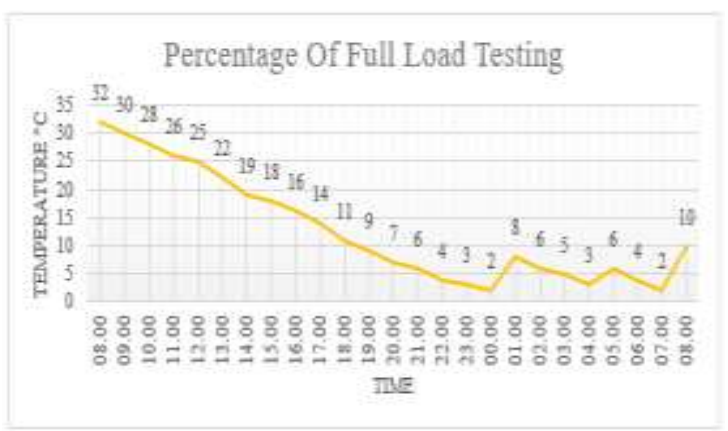

Figure 10. The temperature of Fish Box with Full Load

In a comparison of the time when the load cools the fish, there is a ratio of a long time to reach the desired temperature. The more load fish box then the time required to lower the temperature the longer the fish box. Automated systems used in this study is a system that automatically turns off when certain circumstances. Using two relays that act as switches to death and his life as a refrigerant used and a switch to switch the power supply on the cooler.

\section{CONCLUSION}

After testing of each system and the whole system of design results by the researchers, the tool of the design researchers concluded that:

1) Box designed fish can be used on fishing boats that sail $\leq 2$ days, as the coolant fish because it can produce temperatures below $10^{\circ} \mathrm{C}$, with the lowest temperature is $2^{\circ}$ $\mathrm{C}$, the capacity of $<10 \mathrm{~kg}$.

2) The use of modern systems with an Android application as system monitoring and automatic level controlled cooling performance.

\section{ACKNOWLEDGMENT}

Thanks the author to Allah SWT, blessing the mercy and gift, on this research can be done. Thanks are also given to Universitas Maritim Raja Ali Haji as a place the author studied.

\section{REFERENCES}

[1] Bangun Perangkat Pendingin pada Cumi-Cumi, Universitas Maritim Raja Ali Haji, Tanjungpinang, BAPPEDA, 2016.

[2] Potensi Sumber Daya Laut Cina Selatan, http://bappeda.kepriprov.go.id/index.php/data-informasi/potensidaerah/47-potensi-daerah/201-sektor-perikanan, 2017.

[3] Potret Potensi Kelautan dan Perikanan Provinsi kepulauan Riau 2015, http://kepri.bps.go.id, 2015.

[4] Dakeryadi, dan Pramana, R, "Rancang Bangun Tempat Penyimpanan Ikan Untuk Nelayan, Skripsi, Universitas Maritim Raja Ali Haji, Tanjungpinang, 2017.

[5] Purwiyanti, S., Setyawan., Selviana, W., dan Purnamasari, D, "Aplikasi Efek Peltier Sebagai Kotak Penghangat dan Pendingin Berbasis Mikroprosessor Arduino Uno", Jurnal Rekayasa dan Teknologi Elektro, Universitas Lampung, Bandar Lampung, 2017.

[6] Untung Budiarto, Karyanto, "Optimasi Desain Isolasi Ruang Box ikan KM Berkah 9 GT untuk Mengurangi Laju Perpindahan Panas", Jurnal Teknik Perkapalan, Universitas Diponegoro, Semarang, 2016. 